\title{
Idiopathic Calcium Nephrolithiasis: A Review of Pathogenic Mechanisms in the Light of Genetic Studies
}

\author{
Teresa Arcidiacono ${ }^{a} \quad$ Alessandra Mingione $^{b}$ Lorenza Macrina $^{a}$ \\ Francesca Pivari $^{\mathrm{b}}$ Laura Soldati ${ }^{\mathrm{b}}$ Giuseppe Vezzoli ${ }^{\mathrm{a}}$ \\ aNephrology and Dialysis Unit, IRCCS San Raffaele Scientific Institute and b Department of Health Sciences, \\ Università degli Studi of Milan, Milan, Italy
}

\section{Key Words}

Calcium kidney stones · Calcium excretion · Phosphate excretion $\cdot$ Genetic polymorphism $\cdot$ Randall's plaque

\begin{abstract}
Background: Calcium nephrolithiasis is a multifactorial disease with a polygenic milieu. Association studies identified genetic polymorphisms potentially implicated in the pathogenesis of calcium nephrolithiasis. The present article reviews the mechanisms of calcium stone formation and the potential contribution of gene polymorphisms to lithogenic mechanisms. Summary: Endoscopy observations suggested that precipitation of calcium-oxalate on the Randall's plaque at the papilla surface may cause idiopathic calciumoxalate stones. The Randall's plaque is a hydroxyapatite deposit in the interstitium of the kidney medulla, which resembles a soft tissue calcification. Conversely, calcium-phosphate stones may develop from crystalline deposits located at the tip of the Bellini duct. Polymorphisms of eleven genes have been associated with stones in genome-wide association studies and replicated candidate-gene association studies: VDR, SLC34A1, SLC34A4, CLDN14, and CaSR genes coding for proteins regulating tubular phosphate and calcium reabsorption; CaSR, MGP, OPN, PLAU, and UMOD genes cod-
\end{abstract}

ing for proteins preventing calcium salt precipitation; $A Q P 1$ gene coding for a water channel in the proximal tubule. The renal activity of the last gene, $D G K H$, is unknown. Polymorphisms in these genes may predispose to calcium-oxalate and -phosphate stones by increasing the risk of calciumphosphate precipitation in the tubular fluid. Key Messages: Genetic findings suggest that tubular fluid supersaturation with respect to calcium and phosphate predisposes to calcium-oxalate stones by triggering cellular mechanisms that lead to the Randall's plaque formation.

(c) 2014 S. Karger AG, Basel

\section{Introduction}

Nephrolithiasis is one of the most frequent disorders in western countries. Its prevalence is between 5 and $10 \%$ and calcium nephrolithiasis represents $70-85 \%$ of cases [1]. Studies in families and twin pairs showed that this disease is inherited with a non-mendelian transmission pattern involving multiple genes that explain a half of stone determinants $[2,3]$.

Polymorphisms (SNPs) of eleven genes were associated with calcium kidney stones in case-control studies. Five genes were recognized in replicated studies of candi-

\section{KARGER}

E-Mail karger@karger.com

www.karger.com/ajn
(C) 2014 S. Karger AG, Basel

0250-8095/14/0406-0499\$39.50/0
Dr. Giuseppe Vezzoli, MD

Unità di Nefrologia e Dialisi

IRCCS Istituto Scientifico San Raffaele

Via Olgettina 60, IT-20142 Milano (Italy)

E-Mail vezzoli.giuseppe@ @sr.it 
Table 1. Genes and SNPs associated to calcium nephrolithiasis identified in studies then replicated in different populations

\begin{tabular}{|c|c|c|c|c|c|c|}
\hline Gene & Coded protein & Locus & Origin & Cases/controls, $\mathrm{n} / \mathrm{n}$ & SNP & Ref. \\
\hline CaSR & calcium-sensing receptor & $3 q 21.1$ & Italy & $167 / 214$ & $\begin{array}{l}\text { rs6776158 in the promoter } 1 \\
\text { rs7652589 in } 5^{\prime} \text {-UTR } \\
\text { rs1501899 in intron } 1\end{array}$ & $\begin{array}{l}{[26]} \\
{[27]} \\
{[28]}\end{array}$ \\
\hline VDR & vitamin D receptor & $12 \mathrm{q} 12-14$ & $\begin{array}{l}\text { Italy } \\
\text { India }\end{array}$ & $\begin{array}{l}110 / 127 \\
138 / 166\end{array}$ & $\begin{array}{l}\text { rs } 10735810 \text { of start codon } \\
\text { rs1544410 and rs7975232 in intron } 8 \\
\text { rs731236 in exon } 9\end{array}$ & $\begin{array}{l}{[43]} \\
{[44]}\end{array}$ \\
\hline spp1 & osteopontin & $4 q 22.1$ & $\begin{array}{l}\text { Japan } \\
\text { Japan }\end{array}$ & $\begin{array}{c}45 / 54 \\
249 / 247\end{array}$ & $\begin{array}{l}-145 \text { and }-144 \text { in promoter } \\
-156 \text { in promoter }\end{array}$ & $\begin{array}{l}{[55]} \\
{[56]}\end{array}$ \\
\hline MGP & matrix-gla protein & $12 \mathrm{p} 12.3$ & $\begin{array}{l}\text { Japan } \\
\text { China }\end{array}$ & $\begin{array}{l}122 / 125 \\
374 / 354\end{array}$ & rs 4236 in the exon 4 & $\begin{array}{l}{[63]} \\
{[64]}\end{array}$ \\
\hline PLAU & urokinase & $10 \mathrm{q} 24$ & $\begin{array}{l}\text { Taiwan } \\
\text { Turkey }\end{array}$ & $\begin{array}{c}153 / 105 \\
80 / 40\end{array}$ & rs 4065 in $3^{\prime}$-UTR & $\begin{array}{l}{[58]} \\
{[59]}\end{array}$ \\
\hline
\end{tabular}

Table 2. Genes associated with calcium nephrolithiasis identified by GWASs

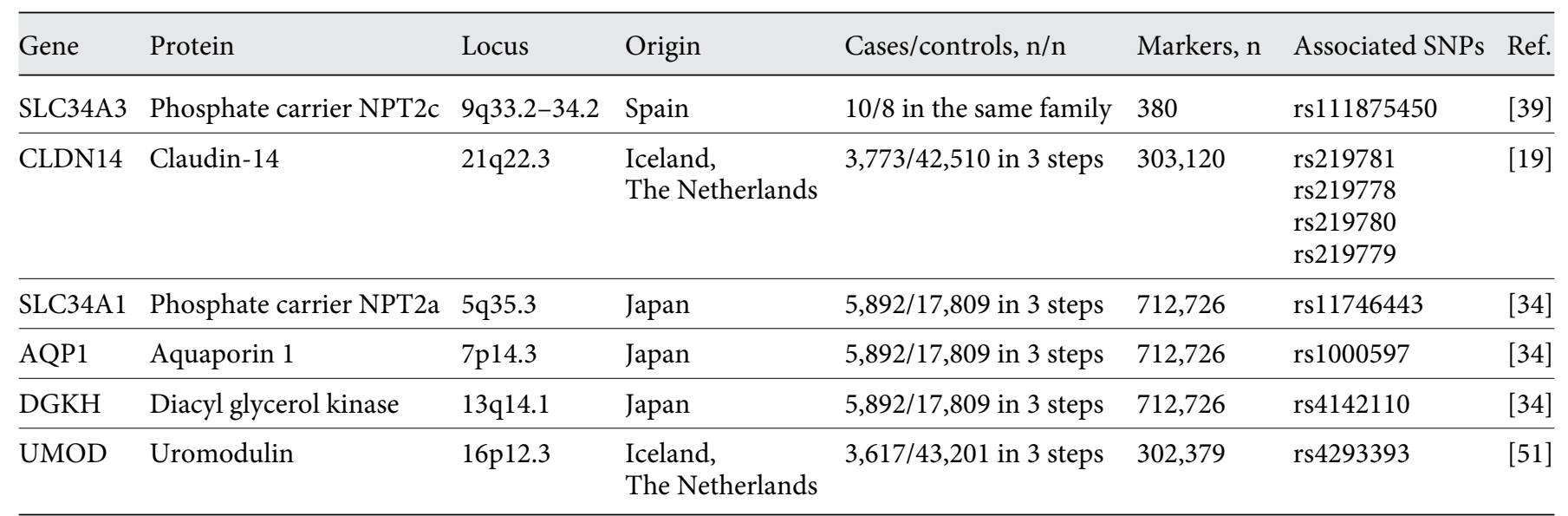

date-genes (table 1). The other six loci were identified in genome-wide association studies (GWASs) mapping the whole genome (table 2). All these genes are expressed in the kidney.

Current pathogenetic hypotheses explain idiopathic calcium-phosphate and -oxalate stones with two different pathways [4]. Calcium-phosphate stone may develop from crystal aggregates deposited at the tip of the Bellini duct $[4,5]$. Calcium-oxalate stones may result from urinary calcium-oxalate precipitation on the Randall's plaque, which is a hydroxyapatite deposit in the interstitium of the kidney medulla $[4,5]$.

The present article reviews current pathogenetic hypotheses explaining idiopathic calcium kidney stones. It also reviews SNPs associated with stones in GWASs or replicated candidate-gene studies and considers the effect of their alleles on the kidney function and the mechanism by which they could contribute to lithogenesis and predispose individuals to calcium stones.

\section{Lithogenic Mechanisms: The Randall's Plaque}

Endoscopy and histology findings indicate that calcium-oxalate stones develop from calcium-oxalate precipitation on portions of the Randall's plaque located at the papilla surface and exposed to the urine flux because of urothelial erosion $[4,5]$. Excessive hydroxyapatite accumulation in the interstitium could be responsible for the urothelial damage $[4,6]$. Therefore, calcium-oxalate stones 
may grow attached to the papilla in the urinary tract as a result of spontaneous calcium-oxalate precipitation on the organic matrix that covers the Randall's plaque [4].

Transmission electron microscopy showed that interstitial deposits of hydroxyapatite consist of multiple spherules with maximal diameter of $10 \mu \mathrm{m}$. Their morphology alternated light and electron dense layers formed by organic or mineral matrix respectively [6]. The organic matrix of these spherules included osteopontin $[4,6]$. The Randall's plaque area at the papillary surface was positively correlated with calcium excretion and stone rate [7].

Histological observations led to the hypothesis that the Randall's plaque arises from the basal membrane of the thin limb of the Henle's loop $[4,6]$. An alternative hypothesis suggested that the Randall's plaque develops from perivascular calcifications of atherosclerotic vasa recta walls $[9,10]$. Indeed, morphologic features of the Randall's plaque recall the soft tissue calcification, which requires the osteogenic transformation of local cells for its formation [11]. The osteogenic transformation was mainly studied in vascular smooth muscle cells (VSMC) that were enabled to synthesize bone proteins when cultured in the presence of high concentrations of calcium and/or phosphate [11, 12]. Also calcium-phosphate nanocrystals (diameter of 30-500 nm) were shown to trigger this process [13]. Conversely, agonists of CaSR and VDR prevented hydroxyapatite deposition by rat and human VSMCs $[11,14,15]$. The achievement of an osteogenic phenotype by kidney cells was hypothesized in genetically hypercalciuric stone forming rats (GHS). The kidney of these rats had higher gene and protein expression levels of osteopontin, bone morphogenetic protein 2 , and osteoblast transcription factors (Runx2 and osterix) than the kidney of control rats [16].

\section{Lithogenic Mechanisms: The Intratubular Precipitation}

Calcium-phosphate stones may develop from spontaneous calcium-phosphate precipitation in the tubular lumen and crystal deposition within the Bellini duct [7]. Crystal aggregates may block and dilate the Bellini duct, thus giving rise to an intratubular nidus from which a calcium-phosphate stone may grow protruding in the urine tract. Tubular fluid supersaturation with respect to calcium and phosphate is the driving force of this lithogenic mechanism and the alkaline $\mathrm{pH}$ of the Henle loop fluid may be crucial to decrease the calcium-phosphate solubility [5]. Tubular cells may internalize crystals and either break them down in lysosomes or deposit them in the interstitium, where local inflammatory reaction may arise $[5,17]$. A deficient inhibition of crystal growth by osteopontin, uromodulin, matrix-gla-protein, and other urine macromolecules may contribute to this mechanism, although in particular conditions they may promote crystal growth $[5,18]$.

\section{Genes and Lithogenesis}

Tables 1 and 2 display genes associated with idiopathic calcium stones in GWASs and replicated candidategene studies in European and Asian populations. GWASs selected stone formers without considering stone composition. Candidate-gene studies selected calcium stone formers, but did not consider the differences in calcium stone composition. Due to the structure of these studies, the selection bias cannot be avoided, but our knowledge about stone composition frequency suggests that findings in these studies are supported by patients suffering from pure or mixed calcium-oxalate stones $[1,5]$.

\section{The CLDN14 Gene}

The CLDN14 gene (21q22.13) was associated with stones in a GWAS including 3,773 stone formers and 42,510 controls from Iceland and the Netherlands. Stones were associated with ancestral alleles at two SNPs located in non-coding regions and two synonymous SNPs, located in the last of the three gene exons. These alleles were also associated with higher calcium excretion and with lower total serum $\mathrm{CO}_{2}$ and bone mineral density [19]. Therefore, it was hypothesized that CLDN14 gene alleles having a positive effect on CLDN14 gene transcription or mRNA processing may predispose to calcium stones.

CLDN14 gene encodes for claudin-14, a 239 amino acid protein [20] expressed in the tight junctions of the thick ascending limb of Henle's loop (TALH), the Corti organ of the inner ear and the liver [21]. Different experiments in lab animals showed that claudin-14 inhibited the paracellular reabsorption of calcium and magnesium in the TALH by closing the channel formed by claudin- 16 and -19 in tight junctions (fig. 1) [22, 23]. High dietary calcium intake, high serum calcium, $1,25(\mathrm{OH})_{2} \mathrm{D}$ administration, and calcimimetic treatment were found to upregulate claudin-14 expression in the TALH in different mouse strains. This suggested that claudin-14 expression 


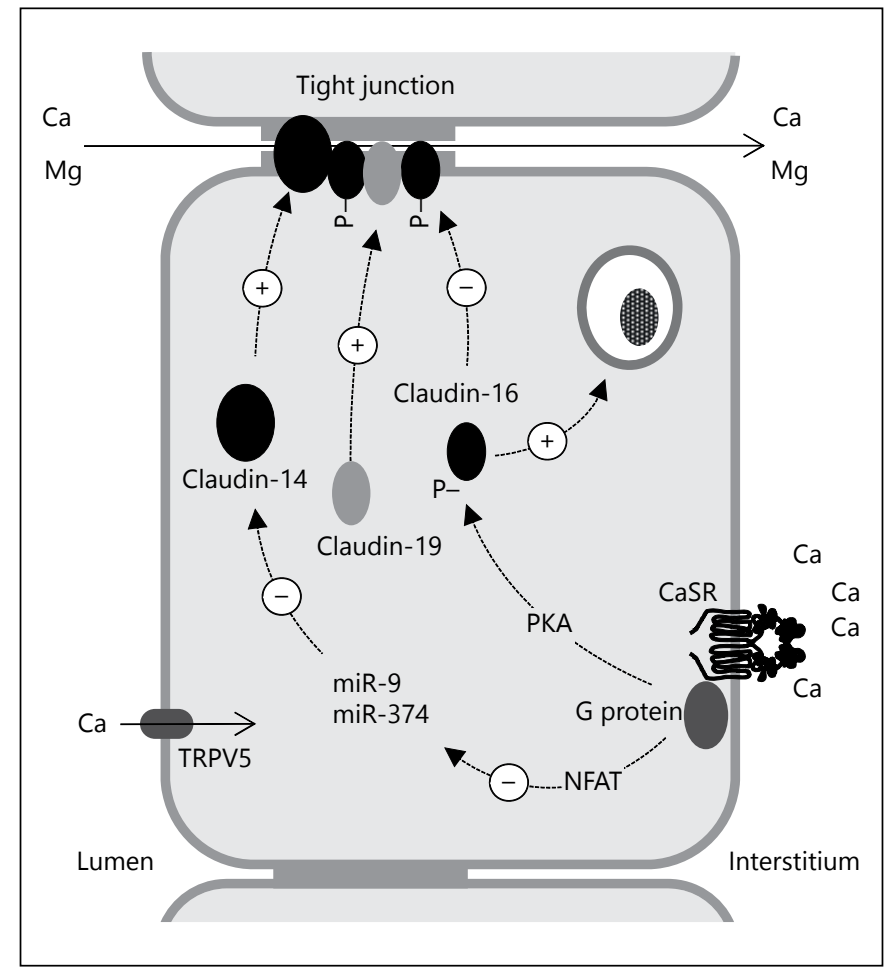

Fig. 1. In TALH cells, claudin-16, -19 and -14 form the tight junction channel for the paracellular passive reabsorption of calcium and magnesium. Claudin 14 inhibits the channel permeability and its expression is enhanced by CaSR through a transcriptional mechanism mediated by the nuclear factor of activated T cell (NFAT) that inhibites the production of two microRNAs, miR-9, and miR-374. CaSR also inhibits claudin-16 phosphorilation and localization in tight junction channels by activating the protein kinase A (PKA). The carrier for calcium ions through the apical cell membrane is the TRPV 5 channel. CaSR activity is mediated by G proteins.

in the TALH was under the control of the extracellular calcium through the calcium-sensing receptor (CaSR) $[22,24]$. In mice, CaSR activation upregulated claudin-14 expression through a histone deacetylation mechanism mediated by the nuclear factor of activated T cells (NFAT) that inhibited the production of two microRNAs, miR-9, and miR-374, modulating the CLDN14 transcription [22, 25]. Claudin-14 may thus regulate calcium reabsorption in response to calcium intake.

\section{The CaSR Gene}

SNPs of the regulatory region of the calcium-sensing receptor (CaSR) gene (3q21.1) were associated with idiopathic calcium stones in two Italian studies $[26,27]$. Another study mapping the $\mathrm{CaSR}$ gene regulatory region ob- served the association of a SNP (rs6776158) sited within the promoter 1 with calcium stones. The minor allele at this SNP was shown to reduce the promoter 1 transcriptional activity in two renal cell models [28].

The CaSR gene (3q13.3-21) codes for a 1,078 amino acid membrane protein ubiquitously expressed as a homodimer. Its molecule includes a large extracellular domain that binds extracellular calcium ions, a seven-membrane spanning domain and a C-terminal intracellular domain interacting with $\mathrm{G}$ proteins and filamin- $\mathrm{A}$ in order to regulate cell functions [29]. CaSR has its largest renal expression in TALH, where it inhibits paracellular calcium reabsorption by enhancing claudin-14 expression and reducing claudin-16 expression (fig. 1). In the TALH, CaSR also decreases the sodium-potassium-chloride cotransport (NKCC2) activity that sustains the electric gradient driving the paracellular calcium reabsorption [24]. CaSR also inhibits active calcium reabsorption in cortical convoluted tubules, as shown in canine tubular cells [30]. In addition to calcium reabsorption, experiments in lab animals showed that CaSR promoted water excretion and urine acidification in the collecting duct through the inhibition of the tubular response to $\mathrm{ADH}$ and the stimulation of proton pump activity, respectively $[31,32]$. In the proximal tubule, CaSR antagonizes phosphate reabsorption and promotes proton secretion through the NHE3 sodium-hydrogen countertransport [33]. Therefore, CaSR activity in the proximal tubule and collecting duct may counterbalance the risk of calciumphosphate precipitation induced by its effect on calcium reabsorption in the TALH and cortical convoluted tubules. A decreased CaSR expression in the kidney might therefore enhance the risk of stone formation by causing an imbalance among its tubular effects.

\section{SLC34A1 and AQP1 Genes}

Three loci, 5q35.3, 7p14.3, and 13q14.1, were associated with calcium nephrolithiasis in a Japanese GWAS including 5,892 cases and 17,809 controls [34]. Three genes at these loci are candidates to explain these associations.

$D G K H$ gene is located at 13q14.1 and encodes for the diacylglycerol kinase, a ubiquitously expressed kinase having unknown functions in the kidney.

The SLC34A1, located at 5q35.3, codes for the phosphate carrier NPT2a, responsible of the $85 \%$ of phosphate reabsorption in the proximal tubule [35]. Knockout-mice for NPT2a developed renal phosphate loss and hypo- 
phosphatemia that led to $1,25(\mathrm{OH}) \mathrm{D}$ hyperproduction and hypercalciuria. Apatite stones were found in the kidney of these mice [36]. SLC34A1 gene SNPs causing a loss of the NPT2a function were detected in hypophosphatemic hypercalciuric patients with osteoporosis or kidney stones and could explain patient phenotype with the same mechanism of knockout-mice $[37,38]$. Interestingly, also the SLC34A3 gene (9q33.2-34.2), which codes for the phosphate carrier NPT2c responsible for the $15 \%$ of the proximal phosphate reabsorption, was identified as a quantitative trait locus for calcium nephrolithiasis in a small study mapping the whole genome in members of a Spanish family [39].

$A Q P 1$, located at $7 \mathrm{p} 14.3$, codes for the water channels AQP1 that supports the transcellular water reabsorption in the proximal tubule [40]. Knockout-mice for AQP1 did not produce stones, but developed dehydration after water deprivation [41]. The AQP1 gene SNPs could impair water reabsorption in proximal tubules and thus stimulate distal mechanisms of urine concentration.

\section{The VDR Gene}

The association of VDR gene (12q12-14) with nephrolithiasis was evidenced in a linkage study in 359 FrenchCanadian sib-pairs [42] and case-control studies in European and Asian populations. Three VDR gene SNPs were identified at the $3^{\prime}$-untranslated end region (UTR) using $B s m I$ ( $B / b$ alleles), ApaI (A/a), TaqI (T/t) restriction enzymes. The first two SNPs were within the intron 8 ; the third was within the exon 9 and was synonymous. The translation start codon SNP was identified using the FokI $(F / f)$ restriction enzyme $[43,44]$. The in-vitro functional study of the 3'-UTR SNPs observed that the baT haplotype diminished VDR gene expression [45]. Unexpectedly, alleles decreasing the VDR expression ( $b$ and $T$ ) or activity $(f)$ were associated with stone risk [43, 46, 47]. Homozygous patients for the $b T$ haplotype showed earlier age of onset, higher stone rate, and lower urinary citrate excretion [43]. Experiments in genetically hypercalciuric stone-forming rats (GHS) showed that selective silencing of the $V D R$ gene in the kidney increased calcium excretion and upregulated the expression of the membrane calcium channels, TRPV5 and TRPV6 [48, 49]. TRPV6 gene SNPs (7q34) were associated with stones in a non-replicated study [50]. In addition to TRPV5/6 genes, the VDR-vitamin $\mathrm{D}$ complex may modulate the expression of CaSR, SLC34A1, SLC34A3, OPN, and MGP [43].

Genes and Pathogenesis of Calcium

\section{UMOD, MGP, OPN, and PLAU Genes}

A SNP next to UMOD gene (16p12.3) was associated with nephrolithiasis in a GWAS in Icelandic and Dutch stone-formers [51]. UMOD gene codes for uromodulin, an inhibitor of calcium-phosphate precipitation. It is mainly synthesized in TALH where it is anchored to plasma membrane glycosylphosphatidylinositols and secreted into the urine after cleavage of its $\mathrm{C}$ terminus [52]. In cultured embryonic renal cells cotransfected with $U M O D$ and TRPV5 genes, uromodulin impaired caveolin-mediated endocytosis. Through this mechanism it could upregulate the expression of the TRPV 5 calcium channels and NKCC2 sodium carrier in the apical membrane of distal tubular cells. As a result, it could enhance calcium reabsorption $[53,54]$.

Two SNPs of the SSP1 gene (4q22.1) coding for osteopontin were associated with stones in stone formers of Japan origin. Both SNPs are located in the gene promoter and may modify gene expression [55]. Another study in a Japanese sample associated stones with SNP sited at -156 (delG/G) in the promoter region [56]. Osteopontin belongs to the family of secreted acidic proteins and binds calcium ions with its negatively charged amino acids. As a consequence, it is a natural inhibitor of soft tissue calcification in humans [57] that may be detected in the organic matrix of calcium stones and hydroxyapatite spherules of the Randall's plaque $[4,5]$.

The SNP rs4065 (C>T), located in the $3^{\prime}$-UTR of the $P L A U$ gene (10q24), was associated with calcium nephrolithiasis in two studies performed in Taiwan and Turkey $[58,59]$. PLAU gene codes for urokinase, a proteolytic enzyme of the serine protease superfamily that cleaves plasminogen to plasmin and stimulates fibrinolysis. In the kidney it may prevent stone formation by cleaving stone matrix proteins [60]. It is likely that the minor allele at rs4065 decreases PLAU gene mRNA stability and expression, causing a decrease of urokinase levels in urine [61].

The MGP gene (12p13.1-p12.3) codes for matrix-glaprotein, a circulating protein containing five vitamin Kdependent carboxylated residues. It inhibits nucleation and growth of hydroxyapatite and calcium-oxalate crystals and may prevent soft tissue calcification and kidney stone formation [62]. Two studies in Japanese and Chinese calcium stone formers found out that an SNP in the exon 4 (rs4236) halved the stone risk [63, 64]. Matrixgla-protein production is stimulated by CaSR-activating drugs and exposure of tubular cells to calcium-oxalate $[65,66]$. 


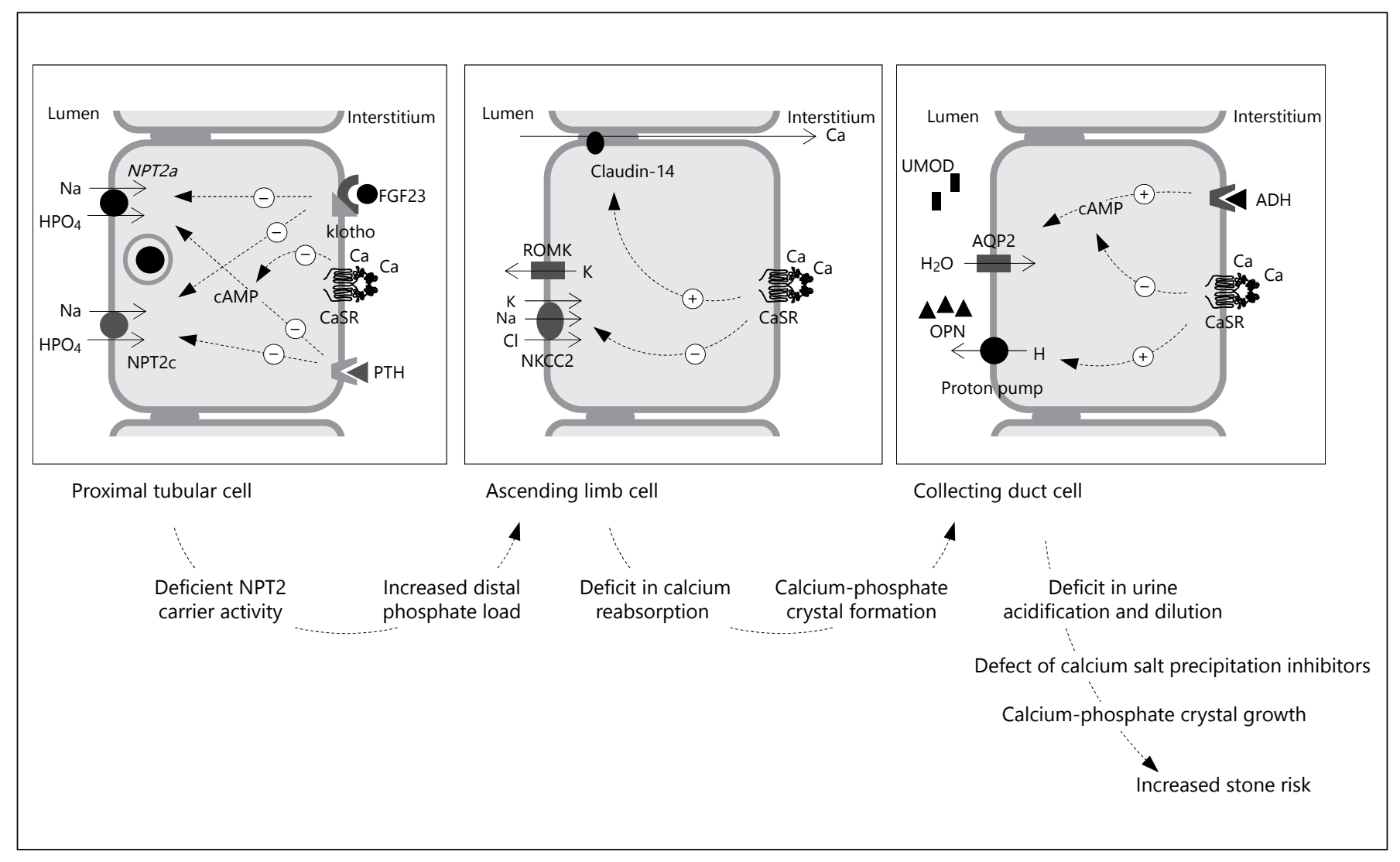

Fig. 2. Genetic studies suggest that stone risk is enhanced by the combination of different modification of tubular functions. In the proximal tubule, a deficient activity of phosphate sodium-phosphate cotransporters (NPT2a and NPT2c) may increase phosphate release to the distal tubule. These carriers are inhibited by fibroblast-growth factor 23 (FGF23) and parathyroid hormone (PTH). CaSR decreases the cAMP-mediated phosphaturic effect of PTH and exerts an antiphosphaturic effect. In the TALH, claudin-14 decreases the paracellular calcium reabsorption. CaSR upregulates claudin-14 expression and inhibits sodium-potassium-

\section{Genetic Polymorphisms and Lithogenic Mechanisms}

Genes associated with calcium kidney stones encode for proteins implicated in the reabsorption of calcium, phosphate, and water and in the activity of precipitation inhibitors (fig. 2). Variant alleles at SLC34A 1/3 and CaSR genes may cause phosphate overload in the distal tubule, while CLDN14 gene SNPs may cause calcium overload in the connecting duct. Variant alleles at MGP, SSP1, PLAU, $U M O D, C a S R$, and $V D R$ genes may decrease the protection against calcium salt precipitation. $A Q P 1$ gene variants may require urine concentration. It is noteworthy that no substantial associations have so far been reported among stones and SNPs at genes regulating oxalate or ci- chloride cotransport (NCCK) activity that maintains the electric driving force for the calcium reabsorption. In the collecting duct, CaSR stimulates proton-pump activity and antagonizes the cAMPmediated effect of the antidiuretic hormone (ADH) on the aquaporin-2 water channel (AQP2). A deficient CaSR expression may therefore decrease tubular cell capability to acidify and dilute urine that predispose to calcium-phosphate precipitation. A deficient activity of uromodulin (UMOD), osteopontin (OPN) and other precipitation inhibitors may contribute to calcium salt precipitation.

trate metabolism. Genetic findings, instead, indicate that SNPs influencing calcium and phosphate reabsorption were involved in calcium-oxalate stone risk. This leads to the conclusion that calcium-phosphate supersaturation in the tubular fluid may predispose to the production of calcium-oxalate stones.

Likely, the Randall's plaque is the factor linking calcium-phosphate supersaturation with calcium-oxalate precipitation in urine [4-8]. The Randall's plaque is a hydroxyapatite deposit in renal interstitium and may be considered a soft tissue calcification; this implies that its formation needs a cell-mediated mechanism [6-10]. The study of vascular calcification in lab animals or cultured VSMCs identified at least three stimuli that may trigger 
cell osteogenic transformation in the kidney: high calcium and phosphate concentrations in the tubular fluid $[11,12]$; a deficient expression of CaSR and VDR in tubular cells $[11,15]$; and the presence of calcium-phosphate nanocrystals in the tubular fluid [13]. Genetic polymorphisms might amplify these osteogenic stimuli in the kidney and enable interstitial or tubular cells to achieve an osteogenic phenotype and deposit hydroxyapatite in the kidney interstitium. In this way SNPs associated with stones could predispose individuals to the formation of the Randall's plaque and calcium-oxalate stones [16].

Physical chemical causes may instead underlie calcium-phosphate stones. SNPs at genes associated with stones may predispose to the intratubular calcium-phosphate precipitation by increasing urine saturation with respect to calcium and phosphate. However, calciumphosphate salts are more often mixed with calcium-oxalate in stones because of their precipitation on calciumoxalate aggregates or Randall's plaque fragments joined to oxalate stones $[5,7]$.
In addition to genes, individual susceptibility to calcium stones may be influenced by dietary habits. Nutrient intake may change urine composition, but may also influence gene expression with epigenetic mechanisms [67]. Interestingly, the larger part of SNPs associated with stones may change gene expression and could consequently modify nutrient effect on gene expression. An example is the epigenetic activation of claudin-14 expression by calcium intake mediated by microRNAs [25], but other studies are needed to explore the interaction between genes and nutrients and to understand better gene involvement in kidney stone production.

In conclusion, available genetic findings emphasize the relevance of renal calcium and phosphate in calcium stone formation and support current pathogenetic hypotheses on calcium stone formation.

\section{Disclosure Statement}

The authors declare no conflict of interest.

\section{References}

1 Croppi E, Ferraro PM, Taddei L, Gambaro G: Prevalence of renal stones in an Italian urban population: a general practice-based study. Urol Res 2012;40:517-522.

-2 Goldfarb DS, Fischer ME, Keich Y, Goldberg $\mathrm{J}$ : A twin study of genetic and dietary influences on nephrolithiasis: a report from the Vietnam Era Twin (VET) Registry. Kidney Int 2005;67:1053-1061

3 Resnick M, Pridgen DB, Goodman HO: Genetic predisposition to formation of calcium oxalate renal calculi. N Engl J Med 1968;278: 1313-1318.

$\checkmark 4$ Evan AP, Lingeman JE, Coe FL, et al: Randall's plaque of patients with nephrolithiasis begins in basement membranes of thin loops of Henle. J Clin Invest 2003;111:607-616.

5 Tiselius HG: A hypothesis of calcium stone formation: an interpretation of stone research during the past decades. Urol Res 2011;39:231-243.

-6 Evan AP, Coe FL, Lingeman JE, et al: Mechanism of formation of human calcium oxalate renal stones on Randall's plaque. Anat Rec 2007;290:1315-1323.

-7 Evan A, Lingeman J, Coe FL, Worcester E: Randall's plaque: pathogenesis and role in calcium oxalate nephrolithiasis. Kidney Int 2006;69:1313-1318.

8 Tiselius HG: The role of calcium phosphate in the development of Randall's plaques. Urolithiasis 2013;41:369-377.

-9 Stoller ML, Low RK, Shami GS, et al: High resolution radiography of cadaveric kidneys: unraveling the mystery of Randall's plaque 17 Merchant ML, Cummins TD, Wilkey DW, et formation. J Urol 1996;156:1263-1266.

10 Stoller ML, Meng MV, Abrahams HM, Kane JP: The primary stone event: a new hypothesis involving a vascular etiology. J Urol 2004;171: 1920-1924.

11 Koleganova N, Piecha G, Ritz E, Schmitt CP, Gross ML: A calcimimetic (R-568), but not calcitriol, prevents vascular remodeling in uremia. Kidney Int 2009;75:60-71.

12 Jono S, McKee MD, Murry CE, et al: Phosphate regulation of vascular smooth muscle cell calcification. Circ Res 2000;87:E10-E17.

13 Sage AP, Lu J, Tintut Y, Demer LL: Hyperphosphatemia-induced nanocrystals upregulate the expression of bone morphogenetic protein-2 and osteopontin genes in mouse smooth muscle cells in vitro. Kidney Int 2011; 79:414-422.

14 Henaut L, Boudot C, Massy ZA, et al: Calcimimetics increase CaSR expression and reduce mineralization in vascular smooth muscle cells: mechanisms of action. Cardiovasc Res 2014;101:256-265.

15 Aoshima Y, Mizobuchi M, Ogata H, et al: Vitamin $\mathrm{D}$ receptor activators inhibit vascular smooth muscle cell mineralization induced by phosphate and TNF- $\alpha$. Nephrol Dial Transplant 2012;27:1800-1806.

16 Jia Z, Wang S, Tang J, et al: Does crystal deposition in genetic hypercalciuric rat kidney tissue share similarities with bone formation? Urology 2014;83:509.e7-509.e14. al: Proteomic analysis of renal calculi indicates an important role for inflammatory processes in calcium stone formation. Am J Physiol Renal Physiol 2008;295:F1254-F1258.

18 Ryall RL, Harnett RM, Hibberd CM, Edyvane KA, Marshall VR: Effects of chondroitin sulphate, human serum albumin and TammHorsfall mucoprotein on calcium oxalate crystallization in undiluted human urine. Urol Res 1991;19:181-188.

19 Thorleifsson G, Holm H, Edvardsson V, et al: Sequence variants in the CLDN14 gene associate with kidney stones and bone mineral density. Nat Genet 2009;412:926-930.

20 Angelow S, Ahlstrom R, Yu AS: Biology of claudins. Am J Physiol Renal Physiol 2008; 295:F867-F876.

21 Ben-Yosef T, Belyantseva IA, Saunders TL, et al: Claudin 14 knockout mice, a model for autosomal recessive deafness DFNB29, are deaf due to cochlear hair cell degeneration. Hum Mol Genet 2003;12:2049-2061.

22 Gong Y, Renigunta V, Himmerkus N, et al: Claudin-14 regulates renal $\mathrm{Ca}^{++}$transport in response to CaSR signaling via a novel microRNA pathway. EMBO J 2012;31:19992012.

23 Toka HR, Al-Romaih K, Koshy JM, et al: Deficiency of the calcium-sensing receptor in the kidney causes parathyroid hormone-independent hypocalciuria. J Am Soc Nephrol 2012;23:1879-1890. 
24 Dimke H, Desai P, Borovac J, Lau A, Pan W, Alexander RT: Activation of the $\mathrm{Ca}(2+)$-sensing receptor increases renal claudin-14 expression and urinary $\mathrm{Ca}(2+)$ excretion. Am J Physiol Renal Physiol 2013;304:F761-F769.

25 Gong Y, Hou J: Claudin-14 underlies $\mathrm{Ca}^{++}$ sensing receptor-mediated $\mathrm{Ca}^{++}$metabolism via NFAT-microRNA-based mechanisms. J Am Soc Nephrol 2014;25:745-760.

26 Vezzoli G, Terranegra A, Arcidiacono T, et al: Calcium kidney stones are associated with a haplotype of the calcium-sensing receptor gene regulatory region. Nephrol Dial Transplant 2010;25:2245-2252.

27 Vezzoli G, Scillitani A, Corbetta S, et al: Polymorphisms at the regulatory regions of the CASR gene influence stone risk in primary hyperparathyroidism. Eur J Endocrinol 2011; 164:421-427.

28 Vezzoli G, Terranegra A, Aloia A, et al. Decreased transcriptional activity of calciumsensing receptor gene promoter 1 is associated with calcium nephrolithiasis. J Clin Endocrinol Metab 2013;98:3839-3847.

-29 Brown EM, MacLeod RJ: Extracellular calcium sensing and extracellular calcium signaling. Physiol Rev 2001;81:239-297.

30 Blankenship KA, Williams JJ, Lawrence MS, McLeish KR, Dean WL, Arthur JM: The calcium-sensing receptor regulates calcium absorption in MDCK cells by inhibition of PMCA. Am J Physiol Renal Physiol 2001; 280:F815-F822.

-31 Sands JM, Naruse M, Baum M, et al: Apical extracellular calcium/polyvalent cation-sensing receptor regulates vasopressin-elicited water permeability in rat kidney inner medullary collecting duct. J Clin Invest 1997;99: 1399-1405.

-32 Casare F, Milan D, Fernandez R: Stimulation of calcium-sensing receptor increases biochemical $\mathrm{H}^{+}$-ATPase activity in mouse cortex and outer medullary regions. Can J Physiol Pharmacol 2014;92:181-188.

33 Capasso G, Geibel PJ, Damiano S, Jaeger P, Richards WG, Geibel JP: The calcium sensing receptor modulates fluid reabsorption and acid secretion in the proximal tubule. Kidney Int 2013;84:277-284.

- 34 Urabe Y, Tanikawa C, Takahashi A, Okada Y, et al: A genome-wide association study of nephrolithiasis in the Japanese population identifies novel susceptible Loci at 5q35.3, 7p14.3, and 13q14.1. PLoS Genet 2012; 8:e1002541.

35 Lapointe JY, Tessier J, Paquette Y, et al: NPT2a gene variation in calcium nephrolithiasis with renal phosphate leak. Kidney Int 2006;69:2261-2267.

36 Chau H, El-Maadawy S, McKee MD, Tenenhouse HS: Renal calcification in mice homozygous for the disrupted type IIa $\mathrm{Na} / \mathrm{Pi}$ cotransporter gene Npt2. J Bone Miner Res 2003; 18:644-657.

37 Prie D, Huart V, Bakouh N, et al: Nephrolithiasis and osteoporosis associated with hypophosphatemia caused by mutations in the type 2a sodium-phosphate cotransporter. $\mathrm{N}$ Engl J Med 2002;347:983-991.

38 Prie D, Ravery V, Boccon-Gibod L, Friedlander G: Frequency of renal phosphate leak among patients with calcium nephrolithiasis. Kidney Int 2001;60:272-276.

39 Wolf MT, Zalewski I, Martin FC, et al: Mapping a new suggestive gene locus for autosomal dominant nephrolithiasis to chromosome 9q33.2-q34.2 by total genome search for linkage. Nephrol Dial Transplant 2005;20:909-914.

40 Schnermann JB, Huang YG, Mizel D: Fluid reabsorption in proximal convoluted tubules of mice with gene deletions of claudin-2 and/ or aquaporin1. Am J Physiol Renal Physiol 2013;305:F1352-F1364.

41 Ma T, Yang B, Gillespie A, Carlson EJ, Epstein CJ, Verkman AS: Severely impaired urinary concentrating ability in transgenic mice lacking aquaporin-1 water channels. J Biol Chem 1998;273:4296-4299.

42 Scott $\mathrm{P}$, Ouimet D, Valiquette L, et al: Suggestive evidence for a susceptibility gene near the vitamin D receptor locus in idiopathic calcium stone formation. J Am Soc Nephrol 1999; 10:1007-1013.

43 Mossetti G, Rendina D, Viceconti R, et al: The relationship of $3^{\prime}$ vitamin $\mathrm{D}$ receptor haplotypes to urinary supersaturation of calcium oxalate salts and to age at onset and familial prevalence of nephrolithiasis. Nephrol Dial Transplant 2004;19:2259-2265.

$\checkmark 44$ Bid HK, Kumar A, Kapoor R, Mittal RD: Association of vitamin D receptor-gene (FokI) polymorphism with calcium oxalate nephrolithiasis. J Endourol 2005;19:111-115.

45 Morrison NA, Qi JC, Tokita A, et al: Prediction of bone density from vitamin $\mathrm{D}$ receptor alleles. Nature 1994;367:284-287.

46 Zhang P, Nie W, Jiang H: Effects of vitamin D receptor polymorphisms on urolithiasis risk: a meta-analysis. BMC Med Genet 2013;14:104.

47 Liu CC, Huang CH, Wu WJ, et al: Association of vitamin D receptor (Fok-I) polymorphism with the clinical presentation of calcium urolithiasis. BJU Int 2007;99:1534-1538.

48 Xi QL, Wang SG, Ye ZQ, Zhu ZW, Li C, Bai J, $\mathrm{Yu}$ X, Liu JH: Effect of silencing VDR gene in kidney on renal epithelial calcium transporter proteins and urinary calcium excretion in genetic hypercalciuric stone-forming rats. Urology 2011;78:1442.e1-1442.e7.

49 Frick KK, Asplin JR, Favus MJ, Culbertson C, Krieger NS, Bushinsky DA: Increased biological response to $1,25(\mathrm{OH})(2) \mathrm{D}(3)$ in genetic hypercalciuric stone-forming rats. Am J Physiol Renal Physiol 2013;304:F718-F726.

50 Suzuki Y, Pasch A, Bonny O, Mohaupt MG, Hediger MA, Frey FJ: Gain-of-function haplotype in the epithelial calcium channel TRPV6 is a risk factor for renal calcium stone formation. Hum Mol Genet 2008;17:1613-1618.

51 Gudbjartsson DF, Holm H, Indridason OS, et al: Association of variants at UMOD with chronic kidney disease and kidney stones-role of age and comorbid diseases. PLoS Genet 2010;6:e1001039.
52 Santambrogio S, Cattaneo A, Bernascone I, et al: Urinary uromodulin carries an intact $\mathrm{ZP}$ domain generated by a conserved C-terminal proteolytic cleavage. Biochem Biophys Res Commun 2008;370:410-413.

53 Wolf MT, Wu XR, Huang CL: Uromodulin upregulates TRPV 5 by impairing caveolin-mediated endocytosis. Kidney Int 2013;84:130-137.

54 Mutig K, Kahl T, Saritas T, et al: Activation of the bumetanide-sensitive $\mathrm{Na}+, \mathrm{K}+, 2 \mathrm{Cl}-\mathrm{co}-$ transporter (NKCC2) is facilitated by TammHorsfall protein in a chloride-sensitive manner. J Biol Chem 2011;286:30200-30210.

55 Gao B, Yasui T, Itoh Y, et al: Association of osteopontin gene haplotypes with nephrolithiasis. Kidney Int 2007;72:592-598.

56 Liu CC, Huang SP, Tsai LY, et al: The impact of osteopontin promoter polymorphisms on the risk of calcium urolithiasis. Clin Chim Acta 2010;411:739-743.

57 Xie Y, Sakatsume M, Nishi S, et al: Expression, roles, receptors, and regulation of osteopontin in the kidney. Kidney Int 2001;60:16451657.

58 Tsai FJ, Lin CC, Lu HF, Chen HY, Chen WC: Urokinase gene $3^{\prime}$-UTR T/C polymorphism is associated with urolithiasis. Urology 2002;59: 458-461.

59 Ozturk M, Kordan Y, Cangul H, et al: Association of urokinase gene $3^{\prime}$-UTR T/C polymorphism with calcium oxalate urolithiasis in children. Int Urol Nephrol 2008;40:563-568.

60 Van Aswegen CH, Dirksen van Sckalckwyk JC, du Toit PJ, Verster L, Franz RC, du Plessis DJ: The effect of calcium and magnesium ions on urinary urokinase and sialidase activity. Urol Res 1992;20:41-44.

61 Mittal RD, Bid HK, Kumar A, et al: Association of urokinase gene $3^{\prime}$-UTR polymorphism with calcium oxalate nephrolithiasis. J Endourol 2006;20:157-160.

62 Schurgers LJ, Barreto DV, Barreto FC, et al: The circulating inactive form of matrix gla protein is a surrogate marker for vascular calcification in chronic kidney disease: a preliminary report. Clin J Am Soc Nephrol 2010;5:568-575.

63 Gao B, Yasui T, Itoh Y, Tozawa K, Hayashi Y, Kohri K: A polymorphism of matrix Gla protein gene is associated with kidney stones. J Urol 2007;177:2361-2365.

64 Lu X, Gao B, Liu Z, et al: A polymorphism of matrix Gla protein gene is associated with kidney stone in the Chinese Han population. Gene 2012;511:127-130.

65 Goiko M, Dierolf J, Gleberzon JS, et al: Peptides of Matrix Gla protein inhibit nucleation and growth of hydroxyapatite and calcium oxalate monohydrate crystals. PLoS One 2013;8:e80344.

66 Lian JB, Prien EL Jr, Glimcher MJ, Gallop PM: The presence of protein-bound gamma-carboxyglutamic acid in calcium-containing renal calculi. J Clin Invest 1977;59:1151-1157.

67 Zaidi SK, Young DW, Montecino MA, et al: Mitotic bookmarking of genes: a novel dimension to epigenetic control. Nat Rev Genet 2010;11:583-589. 